\title{
CHALLENGES OF TWENTY-FIRST CENTURY CONFLICTS: A LOOK AT DIRECT PARTICIPATION IN HOSTILITIES
}

\author{
JAMIE A. WILLIAMSON*
}

\begin{abstract}
During times of armed conflict, whether characterized as international or non-international, International Humanitarian Law ("IHL") is applicable. As a body of law, IHL does not question the lawfulness of a conflict (jus ad bellum) but seeks instead to apply humanitarian principles in warfare (jus in bello). IHL recognizes that even war has its limits, irrespective of its cause, and strives to establish humanitarian parameters to the means and methods of warfare and to alleviate the suffering that conflict so often causes to persons not taking part in the hostilities. The core IHL instruments are the four Geneva Conventions of 1949, their two Additional Protocols of 1977, and Additional Protocol III of 2005. The International Committee of the Red Cross ("ICRC") has been entrusted by states that are parties to the four Geneva Conventions and their Additional Protocols, ${ }^{1}$ and
\end{abstract}

* Legal Advisor for the International Committee of the Red Cross Regional Delegation for the United States and Canada. The views and opinions expressed in this article are mine alone and do not necessarily reflect those of the ICRC.

1. For instance, Articles 9, 9, 9 and 10 respectively of the four Geneva Conventions provide that "the present Convention constitute[s] no obstacle to the humanitarian activities which the International Committee of the Red Cross . . . may, subject to the consent of the Parties to the conflict concerned, undertake for the protection of the wounded and sick, medical personnel and chaplains, and for their relief." Convention for the Amelioration of the Condition of the Wounded and Sick in Armed Forces in the Field art. 9, Aug. 12, 1949, 75 U.N.T.S. 31 [hereinafter Geneva Convention I]; Convention for the Amelioration of the Condition of the Wounded, Sick, and Shipwrecked Members of Armed Forces at Sea art. 9, Aug. 12, 1949, 75 U.N.T.S. 85 [hereinafter Geneva Convention II]; Convention Relative to the Treatment of Prisoners of War art. 9, Aug. 12, 1949, 75 U.N.T.S 135 [hereinafter Geneva Convention III]; Convention Relative to the Protection of Civilian Persons in Time of War art. 10, Aug. 12, 1949, 75 U.N.T.S. 287 [hereinafter Geneva Convention IV]. Article 3 common to the four Geneva Conventions reads, "An impartial humanitarian body, such as the International Committee of the Red Cross, may offer its services to the Parties to the conflict." Geneva Convention I, supra note 1, art. 3; Geneva Convention II, supra note 1, art. 3; Geneva Convention III, supra note 1, art. 3; Geneva Convention IV, supra note 1, art. 3. Article 126 of the Third Geneva Convention and Article 143 of the Fourth Geneva Convention recognize that the ICRC has permission to go to all places where protected persons may be, in particular those deprived of liberty, have access to all premises occupied by them, interview them without witnesses, and have full liberty to select the places of visit as well as the duration and frequency of the visits. The ICRC's mission is to protect and assist the civilian and military victims of armed conflicts and internal disturbances on a strictly neutral and impartial basis and to promote compliance with IHL. The ICRC's global presence is adjusted to respond to armed conflicts 
through the Statutes of the International Red Cross and Red Crescent Movement ("Statutes"), ${ }^{2}$ with the "guardianship" of IHL.

Tracing the history of the development of International Humanitarian Law during the twentieth century, it could be argued that IHL evolved to address new humanitarian concerns arising from the then existing conflicts. Thus after the Second World War, we saw states calling for greater protection of civilians during armed conflicts and an extension of the earlier Conventions to better address concerns relative to wounded and sick in armed forces in the field and at sea, and to prisoners of war. The addition of Common Article 3 to the four Geneva Conventions marked an important step forward in that, even in non-international armed conflicts, a minimum of protections would be ensured for persons taking no part in hostilities or those who are hors de combat.

Similarly, with the adoption of the two additional Protocols in 1977, more than a quarter of a century later, states sought to deal with aspects of human suffering not covered by the 1949 Geneva Conventions. Provisions on the conduct of hostilities and of combatants, traditionally found within the "Law of the Hague," were included. ${ }^{3}$ Additional Protocol II represented the first international instrument dedicated to the protection of victims of non-international armed conflicts. With the Geneva Conventions having been ratified universally and the 1977 Additional Protocols ratified by the vast majority of states, the international community has voiced its commitment to the principles contained in these instruments and to respecting and ensuring the respect of $\mathrm{IHL}^{4}$

and other situations of violence; it currently has offices in 80 countries with over 12,000 staff worldwide. INT'L COMM. OF THE RED CROSS, THE ICRC: ITS Mission AND WORK 3-5 (2009), http:// www.icrc.org/Web/Eng/siteeng0.nsf/htmlall/p0963/\$File/ICRC_002_0963.PDF.

2. The Statutes of the International Red Cross and Red Crescent Movement were adopted by the 25th International Conference of the Red Cross at Geneva in October 1986 and as amended in 1995 and 2006. Statutes of the Int'l Red Cross and Red Crescent Movement, http://www.icrc.org/Web/ eng/siteeng0.nsf/htmlall/statutes-movement-220506/\$File/Statutes-EN-A5.pdf (last visited May 19, 2010).

3. The "Law of The Hague" establishes the rights and obligations of belligerents in the conduct of military operations and limits the means of harming the adversary. JENNIFER ELSEA, CRS REP. FOR CONG., TERrorism AND THE LAW OF WAR: TRYING TERRORISTS AS WAR CRIMINALS BEFORE MiLITARY COMMISSIONS (2001), http://www.fas.org/irp/crs/RL31191.pdf. It includes the 1899 Hague Conventions respecting the laws and customs of war on land and the adaptation to maritime warfare and the principles of the 1864 Geneva Convention, as well as the 1907 Review of the Hague Conventions of 1899 and adoption of new Conventions. Id.

4. At the time of writing, the Geneva Conventions have been universally ratified, and 164 States have ratified Additional Protocol I; 168 have ratified Additional Protocol II; and 40 have ratified Additional Protocol III. ICRC.org, The Geneva Conventions of 1949, http://www.icrc.org/web/eng/ siteeng0.nsf/html/genevaconventions (last visited Mar. 22, 2010). 
However, in recent times, armed conflicts have given rise to new challenges and to new humanitarian concerns. The realities of modern day armed conflicts have also fuelled the debate as to the adequacy of IHL in the face of an evolving tapestry of conflict.

Indeed, it could be argued that starting in the early $1990 \mathrm{~s}$, there has been a notable shift away from the manner in which conflicts were traditionally fought, with new actors, new weapons and new tactics. Contemporary armed conflicts are vastly different creatures from those prevailing in the first part of the twentieth century, when states negotiated the texts of the Geneva Conventions. Gone are the days when the belligerents were often easily recognizable and were predominantly members of the regular armed forces of the states confronting one another, as was the case during the First and Second World Wars. Those actively engaged in the fighting then were usually soldiers who stood apart from civilians, and civilians were not seen to be taking any direct part in the hostilities. Combatants would wear military uniforms and carry their weapons openly.

Presently, most armed conflicts are not fought between states in such a traditional fashion. A wide range of highly complex and drawn-out internal conflicts of low intensity are replacing interstate warfare. ${ }^{5}$ Most conflicts usually involve at least one organized non-state armed group, without a clear start or end to the hostilities. Questions of transnational terrorism further add fuel to the fire of violence. Indeed, over the past decade we have witnessed the advent of the so-called global fight against terrorism, also referred to as the global war against al Qaeda and its affiliates.

With this metamorphosis of conflicts, it was suggested that certain aspects of IHL were inadequate to deal with the realities of modern warfare. ${ }^{6}$ IHL was deemed too outdated to effectively address the threats faced in the fight against terrorism. ${ }^{7}$ Thus for instance, much was written

5. For example, see the complex situations in the Democratic Republic of Congo and the Darfur region of Sudan.

6. See, e.g., John H. Richardson, Alberto Gonzalez: What I've Learned, EsQUIRE, Dec. 9, 2009 (quoting former Attorney General Gonzalez: "I used the word quaint in referring to provisions in the Geneva Conventions that require the signatories to provide the prisoners of war privileges like commissary privileges, scientific instruments, athletic uniforms. I think those provisions are quaint. I did not say nor did I intend to say that the basic principles of the Geneva Conventions in providing for humane treatment were quaint. So if I had to do it again, what I would not do is use the word quaint and the Geneva Conventions in the same sentence."); Ronald Watson, Geneva Accords Quaint and Obsolete, Legal Aide Told Bush, TIMESOnLINE, May 19, 2004, http://www.timesonline.co.uk/tol/ news/world/iraq/article426900.ece (last visited Mar. 22, 2010).

7. See, e.g., Al Bihani v. Obama, 594 F. Supp. 2d 35, 44 (D.C. Cir. 2009) (Brown, J., concurring) ("War is a challenge to law, and the law must adjust. It must recognize that the old wineskins of 
about the sufficiency of IHL to tackle the transnational threat posed by terrorism. For the ICRC, there was no one size fits all approach to answering this question. Each situation of violence, whether part of the so called global fight against terrorism or not, needs to be assessed on a caseby-case basis. In other words, only by looking at the facts on the ground, at the parties involved, and nature of the violence, could it be determined whether and to what extent IHL applied to the situation. Individuals at war in the legal sense would be protected by International Humanitarian Law. Outside of legal war, protection would be afforded by other bodies of law, such as human rights law and domestic law. ${ }^{8}$

\section{SOME CLARIFICATION PROCESSES}

Seeking to address some of the challenges posed to IHL by contemporary armed conflicts, in 2003, the ICRC presented a report to the $28^{\text {th }}$ International Conference of the Red Cross and Red Crescent, intended to generate reflection and debate about some of the issues. ${ }^{9}$ In the view of the ICRC, the four Geneva Conventions and their Protocols, other IHL treaties, as well as norms of international customary law, provided a bedrock of principles and rules that must continue to guide the conduct of hostilities and the treatment of persons who have fallen into the hands of a party to an armed conflict. ${ }^{10}$ In 2007 , the ICRC explained further that this body of law "reflect[s] a reasonable and pragmatic balance between the demands of military necessity and those of humanity." 11 For the ICRC, the challenges to IHL were not to be resolved through development of IHL per se, but rather through clarification and further elaboration of the rules and principles contained in this body of law.

The ICRC identified a number of issues raised by modern-day armed conflicts that warranted possible further clarification. These included procedural principles and safeguards for internment or administrative

international law, domestic criminal procedure, or other prior frameworks are ill-suited to the bitter wine of this new warfare.").

8. See Jakob Kellenberger, Challenges Faced by the ICRC and Int'l Humanitarian Law (IHL), available at http://www.icrc.org/web/eng/siteeng0.nsf/html/kellenberger-statement-191006) (last visited Mar. 22, 2010). Jakob Kellenberger was the President of the ICRC at Georgetown University in Washington, D.C. Id.

9. INTERNATIONAL COMMITTEE OF THE RED CROSS, INTERNATIONAL HUMANITARIAN LAW AND THE Challenges of CONTEMPORARY ARMed CONFlicts (2003), http://www.icrc.org/Web/eng/ siteeng0.nsf/htmlall/5TALFN/\$File/Reaf\%20and\%20dev-Main\%20report-Oct\%202003.pdf.

10. Id.

11. InTERNATIONAL COMMITTEE OF THE RED CROSS, INTERNATIONAL HUMANITARIAN LAW AND THE CHALlENGES OF ARMED CONFLICTS 4 (2007), http://www.icrc.org/Web/eng/siteeng0.nsf/htmlall/ ihl-30-international-conference-101207/\$File/IHL-challenges-30th-International-Conference-ENG.pdf. 
detention, particularly in connection with the fight against terrorism, the regulation of private military and security companies, increasing the respect for IHL and the role of sanctions. They also covered aspects of the conduct of hostilities, including the use of certain weapons such as cluster munitions, direct participation in hostilities and the protection of persons in the midst of non-international armed conflicts. ${ }^{12}$

This process of clarification is a work in progress, though there have already been certain notable outcomes. In 2005, the ICRC issued a set of procedural principles and safeguards applicable to any situation of internment. These have been relied upon by the ICRC in its operational dialogue with detaining authorities in a number of contexts. ${ }^{13}$

In 2008, as the outcome of an initiative launched cooperatively by the Government of Switzerland and the ICRC, the Montreux Document on Pertinent International Legal Obligations and Good Practices for States Related to Operations of Private Military and Security Companies During Armed Conflict was published. ${ }^{14}$

Also in 2008, the Convention on Cluster Munitions was adopted by 107 states at a diplomatic conference held in Dublin, Ireland, and opened for signature on December 3, 2008 at a treaty signing ceremony in Oslo,

12. Id.

13. See Jelena Pejic, Procedural Principles and Safeguards for Internment/Administrative Detention in Armed Conflict and Other Situations of Violence, 87 INT'L REV. RED CROSS 858 at 379 (2005), quoting International Covenant on Civil and Political Rights art. 4(1), Aug. 12, 1949, 999 U.N.T.S. 171, 1057 U.N.T.S. 407.

14. Letter, General Assembly Security Council, Status of the Protocols Additional to the Geneva Conventions of 1949 and Relating to the Protection of Victims of Armed Conflicts, U.N. Doc. A/63/467-S/2008/636 (Oct. 6, 2008) [hereinafter Montreux Document]. The document was developed with the participation of governmental experts from Afghanistan, Angola, Australia, Austria, Canada, China, France, Germany, Iraq, Poland, Sierra Leone, South Africa, Sweden, Switzerland, the United Kingdom of Great Britain and Northern Ireland, Ukraine, and the United States of America in meetings convened in January and November 2006, November 2007, and April and September 2008. A number of representatives of civil society, NGOs, and of the private military and security industry were consulted as part of the process. There are currently 34 states that support the Montreux Document. Seventeen states jointly finalized the document on the occasion of a concluding meeting in Montreux, Switzerland, on September 17, 2008. The following additional states have joined the Montreux Document since its release, with date of communication of support: Macedonia (Feb. 3, 2009), Ecuador (Feb. 12, 2009), Albania (Feb. 17, 2009), the Netherlands (Feb. 20, 2009), Bosnia and Herzegowina (Mar. 9, 2009), Greece (Mar. 13, 2009), Portugal (Mar. 27, 2009), Chile (Apr. 6, 2009), Uruguay (Apr. 22, 2009), Liechtenstein (Apr. 27, 2009), Qatar (Apr. 30, 2009), Jordan (May 18, 2009), Spain (May 20, 2009), Italy (June 15, 2009), Uganda (July 23, 2009), Cyprus (Sept. 29, 2009), Georgia (Oct. 22, 2009). Participating States of the Montreux Document, http://www.eda.admin.ch/eda/en/home/topics/ intla/humlaw/pse/parsta.html (last visited Apr. 4, 2010). 
Norway. To date, it has been ratified by 32 states, and it will enter into force on August 1, 2010. ${ }^{15}$

More recently, in May 2009, the ICRC issued its Interpretive Guidance on the notion of direct participation in hostilities under International Humanitarian Law (the "Guidance").

To be sure, the realization of each of these outcomes has not been without debate and some interesting exchanges. However, given the complexity of contemporary armed conflicts, this discussion is to be expected. The more contentious area, and the more troubling from a humanitarian perspective, relates to the loss of protection of civilians who directly participated in hostilities.

\section{DIRECT PARTICIPATION IN HOSTILITIES}

Under IHL, parties to a conflict must at all times distinguish between civilians and combatants. Attacks may only be directed against combatants, and cannot be directed against civilians. ${ }^{16}$ However, civilians can lose their protection from direct attack when and "for such time as they take a direct part in hostilities." ${ }^{\prime \prime}$ The immunity from direct attack to which civilians are entitled is one of the lynchpins of IHL. Civilians do not lose their immunity for mere contribution to the general war effort, usually carried out far from the battlefield. However, their protection is granted subject to their

15. The Convention on Cluster Munitions prohibits all use, stockpiling, production and transfer of Cluster Munitions. It is the result of the "Oslo-process" which was launched in February 2007, when forty-six States agreed to the Oslo Declaration which reads: "Conclude by 2008 a legally binding international instrument that prohibits the use and stockpiling of cluster munitions that cause unacceptable harm to civilians and secure adequate provision of care and rehabilitation to survivors and clearance of contaminated areas." Oslo Conference on Cluster Munitions, Declaration, Feb. 22-23, 2007, available at $\mathrm{http}: / / \mathrm{www} . c l u s t e r c o n v e n t i o n . o r g / d o w n l o a d a b l e f i l e s / O s l o \% 20 D e c l a r a t i o n F e b 07 . p d f$.

16. Protocol Additional to the Geneva Conventions of 12 August 1949, and relating to the Protection of Victims of International Armed Conflicts arts. 48, 51(1) and 52(2), June 8, 1977 [hereinafter Protocol I]; Protocol Additional to the Geneva Conventions of 12 August 1949, and relating to the Protection of Victims of Non-International Armed Conflicts art. 13(2), June 8, 1977 [hereinafter Protocol II]. See also Jean-Marie Henckaerts \& Louise Doswald-Beck, Customary INTERNATIONAL HUMANITARIAN LAW, VOLUME I: RUles 8-11 (Cambridge Univ. Press 2005) [hereinafter HENCKAERTS \& DOSWALD-BECK]; see also JUDGE ADVOCATE GENERAL's SCHOOL, INT'L AND OPERATIONAL LAW DEPT., OPERATIONAL LAW HANDBOOK 16 (2009) [hereinafter OPERATIONAL LAW HANDBOOK] ("Sometimes referred to as the principle of discrimination, this principle requires that combatants be distinguished from non combatants, and that military objectives be distinguished from protected property or protected places. In keeping with this 'grandfather' principle of the [Law of War], parties to a conflict must direct their operations only against combatants and military objectives.”)

17. Protocol I, supra note 16, art. 15(3); Protocol II, supra note 16, art. 13(3). See also HENCKAERTS \& DOSWALD-BECK, supra note 16, at 19-24. 
abstention from all direct participation in hostilities during armed conflicts. Failure to do so leaves them open to direct attack. ${ }^{18}$

With the changing nature of warfare though, there has been not only increased civilian involvement in acts closely related to actual combat, but also a lessening distinction between civilians and belligerents, especially on the side of non-state actors involved in non-international armed conflicts. With this blurring of actors, determining who is a lawful target becomes a much more complex assessment for the parties to the conflict. This blurring also puts civilians at greater risk of being in harm's way during the hostilities.

The Guidance, an institutional publication of the ICRC, represented the outcome of an expert process conducted from 2003 to 2008. The ICRC held several meetings during this period which brought together nearly 50 legal experts from academic, military, governmental, and nongovernmental circles, all of whom attended in their personal capacity. ${ }^{19}$ The Guidance is influenced by the expert discussions, but does not necessarily reflect a majority opinion of the participating experts on the various issues addressed. $^{20}$

As explained in its introduction, the Guidance interprets the notion of direct participation in hostilities for the purposes of the conduct of hostilities only. ${ }^{21}$ In other words, the Guidance focuses on whether and for how long a person is considered to have lost protection from direct attack because he or she is directly participating in hostilities. The Guidance does not look at what happens to an individual after he has directly participated in hostilities, and for instance finds himself detained by the adversary.

The Guidance presents ten recommendations, from defining who is a civilian in armed conflicts to explaining that which constitutes direct participation in hostilities and the consequence of so participating. Without

18. Jean Pictet et al., Commentary on the Additional Protocols of 8 June 1977 to the GENEVA CONVENTIONS OF 12 August 1949 §§ 1942-1945 (1987) [hereinafter PiCTET COMMENTARY].

19. All materials produced in the course of the expert process are available at www.icrc.org.

20. As explained in the Introduction to the Guidance: "The Interpretive Guidance is widely informed by the discussions held during these expert meetings but does not necessarily reflect a unanimous view or majority opinion of the experts. It endeavours to propose a balanced and practical solution that takes into account the wide variety of concerns involved and, at the same time, ensures a clear and coherent interpretation of the law consistent with the purposes and principles of IHL. Ultimately, the responsibility for the Interpretive Guidance is assumed by the ICRC as a neutral and independent humanitarian organization mandated by the international community of States to promote and work for a better understanding of IHL." INTERNATIONAL COMMITTEE OF THE RED CROSS, INTERPRETIVE GUIDANCE ON THE NOTION OF DiRECT PARTICIPATION IN HOSTILITIES UNDER INTERNATIONAL HUMANITARIAN LAW 9-10 (2009) [hereinafter GUIDANCE], available at http:// www.icrc.org/Web/Eng/siteeng0.nsf/htmlall/p0990/\$File/ICRC_002_0990.PDF.

21. Id. at 10-11. 
seeking to be comprehensive, the following is an overview of the recommendations and of some of the questions that arose during the expert process.

The first recommendation defines civilians in international armed conflict as being "all persons who are neither members of the armed forces of a party to the conflict nor participants in a levée en masse." 22 Similarly, in the context of non-international armed conflicts, the second recommendation states that civilians are "all persons who are not members of State armed forces or organized armed groups of a party to the conflict and are therefore entitled to protection against direct attack unless and for such time as they take a direct part in hostilities." ${ }^{23}$

The Guidance explains that in non-international armed conflicts, organized armed groups constitute the armed forces of a non-state party to the conflict and consist only of individuals whose constant function is to take a direct part in hostilities, or, in other words, individuals who have a continuous combat function. This functional, rather than membership, approach takes into the account the reality of structures and membership of irregularly constituted groups, where membership is rarely formal or made obvious through the wearing of uniforms or fixed insignia. As such, the Guidance notes that other factors should be taken into account. Repeated direct participation in hostilities, for instance, may be an indicator of having a continuous combat function. In case of doubt, the individual must be considered a civilian entitled to protection from direct attack.

Individuals accompanying and supporting such organized groups and whose functions do not involve direct participation in hostilities remain civilians, and are not subject to direct attack. Examples of such civilians include recruiters, trainers, and financiers, as well as purchasers and smugglers of equipment. Of course, by virtue of accompanying the organised armed groups, they may be at greater risk of being in harm's way during hostilities. Nonetheless, as with other civilians, they remain protected from "direct attack unless and for such time as they directly participate in hostilities." 24

In the same vein, recommendation three states that private contractors and civilian "employees of a party to an armed conflict who are

22. Id. at 20. Members of a levée en masse are "[i]nhabitants of a non-occupied territory, who on the approach of the enemy spontaneously take up arms to resist the invading forces, without having had time to form themselves into regular armed units provided that they carry arms openly and respect the laws and customs of war." Geneva Convention Relative to the Treatment of Prisoners of War art. 4(6), Aug. 12, 1949, 6 U.S.T. 3316, 75 U.N.T.S. 135.

23. GUIDANCE, supra note 20, at 27.

24. Id. at $34-35$. 
civilians ... are entitled to protection against direct attack unless and for such time as they take a direct part in hostilities." ${ }^{25}$ However, their activities and presence alongside the armed forces and military objectives may expose them to an increased risk of incidental death or injury. ${ }^{26}$

This reading of the status of personnel of Private Military and Security Companies ("PMSCs") reflects the conclusion of the Montreux Document on Pertinent International Legal Obligations and Good Practices for States Related to Operations of Private Military and Security Companies During Armed Conflict. ${ }^{27}$ According to the Montreux Document, the status of the personnel of private security and military contractors in armed conflict situations is to be determined by International Humanitarian Law on a caseby-case basis, with particular regard to the nature and circumstances of the functions in which they are involved. However, there is a presumption that personnel of PMSCs are protected as civilians under IHL unless they are incorporated into the regular armed forces of a state or are members of organized armed forces, groups or units under a command responsible to the state. As with other civilians under IHL, personnel of PMSCs may not be the object of attack, unless and for such time as they directly participate in hostilities.

Recommendations four, five, and six look specifically at the nature of the acts that could constitute direct participation in hostilities and seek to provide temporal as well as geographical outer limits to specific acts. The fourth recommendation sets the standard, by explaining that the "[n]otion of direct participation in hostilities refers to specific acts carried out by individuals as part of the conduct of hostilities between parties to an armed conflict." ${ }^{28}$ Recommendation five of the Guidance then advances cumulative criteria to be met for an act to qualify as direct participation in hostilities, termed as (i) threshold of harm, (ii) direct causation, and (iii) belligerent nexus. First, "the act must be likely to adversely affect the military operations or military capacity of a party to an armed conflict or, alternatively, to inflict death, injury, or destruction on persons or objects protected against direct attack." 29 Second, "there must be a direct causal link between the act and the harm likely to result either from that act, or from a coordinated military operation of which that act constitutes an integral part." ${ }^{30}$ And third, "the act must be specifically designed to directly

\footnotetext{
25. Id. at 37 .

26. Id. at 38 .

27. See Montreux Document, supra note 14.

28. GUIDANCE, supra note 20, at 43-45.

29. Id. at 47.

30. Id. at 51 .
} 
cause the required threshold of harm in support of a party to the conflict and to the detriment of another.", 31

Finally, recommendation six provides guidance as to the beginning and end of an act said to constitute direct participation in hostilities by stipulating that "measures preparatory to the execution of a specific act of direct participation in hostilities, as well as the deployment to and the return from the location of its execution, constitute an integral part of that act." 32

During discussions on the direct causation criteria, experts were careful to draw a distinction between direct participation in hostilities and indirect participation-notably, assisting the general war effort and war sustaining activities. While some forms of indirect participation may adversely affect the military effort of a party to the conflict, according to the Guidance, indirect participation does not entail the loss of protection from direct attack. ${ }^{33}$

This distinction between acts merely building the military capacity of one of the parties to the conflict and those acts intended to actually cause harm was discussed during the experts meetings. ${ }^{34}$ According to this distinction, a civilian worker in an ammunitions factory is not directly participating in hostilities, but merely supporting the general war effort. Unlike the civilian who actually uses the ammunition to harm the adversary, the factory worker has not lost his protection under IHL and is not subject to direct attack. Other examples of indirect forms of participation that were cited include design, production, and shipment of weapons and military equipment, recruitment and training of personnel, and political propaganda. The experts felt that whether an act had "sufficient" causal link to qualify as direct participation in hostilities could not be objectively measured, and had to be assessed on a case-by-case basis. $^{35}$

31. Id. at 58 .

32. Id. at 65 .

33. Id. at 54-56.

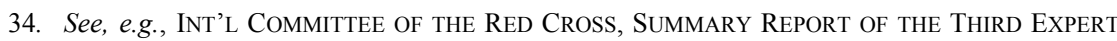
MEETING ON THE NOTION OF DiRECT PARTICIPATION IN HOSTILITIES (2005), available at http:// www.icrc.org/Web/eng/siteeng0.nsf/htmlall/direct-participation-article-020709/\$File/2005-09-reportdph-2005-icrc.pdf.

35. For a similar approach, see The Manual of the Law of Armed Conflict, UK Ministry of Defence (Oxford University Press 2004), at 5.3.3: Whether civilians are taking a direct part in hostilities is a question of fact. Civilians manning an anti-aircraft gun or engaging in sabotage of military installations are doing so. Civilians working in military vehicle maintenance depots or munitions factories or driving military transport vehicles are not, but they are at risk from attacks on those objectives since military objectives may be attacked whether or not civilians are present. 
It was also indicated by experts that the direct causation standard should not be equated with a "but for" test or with "aiding and abetting," given that both of these would include activities which the experts agreed would be indirect rather than direct participation. ${ }^{36}$ Indeed, the Appeals Chamber of the International Criminal Tribunal for the Former Yugoslavia ("ICTY") has described direct participation in hostilities as "acts of war which by their nature or purpose are intended to cause actual harm to the personnel or equipment of the enemy's armed forces. Such an enquiry must be undertaken on a case-by-case basis . ..."37

Recommendations six and seven delve into the temporal parameters of direct participation in hostilities. Recommendation six was discussed in part above. Recommendation seven states that

[c]ivilians lose protection against direct attack for the duration of each specific act amounting to direct participation in hostilities, whereas members of organized armed groups belonging to a non-state party to an armed conflict cease to be civilians and lose protection against direct attack for as long as they assume their continuous combat function. ${ }^{38}$

The scope of the loss of protection, both in terms of the integral elements of each specific act, as well in relation to civilians who participate in hostilities in a recurrent manner, was one of the more difficult issues to be analyzed. IHL indicates that civilians can be the subject of attack "for such time" as they directly participate in hostilities, and that they regain protection thereafter. As explained in the commentary to Additional Protocol I, "[i]f a civilian participates directly in hostilities, it is clear that he will not enjoy any protection against attacks for as long as his participation lasts. Thereafter, as he no longer presents any danger for the adversary, he may not be attacked." ${ }^{, 39}$ During the experts' meetings there was much discussion on the parameters of the beginning and end of direct participation for each act. This also gave rise to the consideration of the 'revolving door' concept, whereby civilians lose protection only for such time as they engage in direct participation in hostilities. ${ }^{40}$

36. Id. at 34 .

37. Prosecutor v. Pavle Strugar, Case No. IT-01-42-A, ICTY, § 178 (17 July 2008).

38. GUIDANCE, supra note 20, at 70-73.

39. Pictet COMMENTARY, supra note $18, \S 4789$.

40. See, e.g., InT'L COMmittee of the Red Cross, Summary RePort of the Fifth EXPERT MeEting on the Notion of DiRect PARTiCiPATION In Hostilities 33-44 (2008) [hereinafter 2008 Report], available at http://www.icrc.org/Web/eng/siteeng0.nsf/htmlall/direct-participation-article020709/\$File/2008-05-report-dph-2008-icrc.pdf. 
The first question in essence then, is when does direct participation effectively start and end? Can it be said that direct participation is limited to the actual execution of the hostile act itself, for instance the actual laying and detonating of the Improvised Explosive Device ("IED"), or does it also include the build up to the act of direct participation, for instance assembling the IED in a garage for use the next day, as well the deployment to and return from the location of the act?

The Guidance recognizes that civilians can be subject to attack when undertaking preparatory measures to the execution of the act, deploying to the location and returning from the location of the execution of the act. Preparatory acts are simply described with reference to Article 44(3) of Additional Protocol I, as acts which are of a specifically military nature and so closely linked to the subsequent execution of the hostile act that they already constitute an integral part of that act. ${ }^{41}$ The discussions of the experts demonstrated the challenge in coming up with a workable standard and timeframe. It was recognized that utmost care was needed in making the determinations, balancing the humanitarian consequence of subjecting an individual to direct attack against the need for the military to attack during preparatory phases, seeing that this could be the only opportunity to deter and defeat a lethal attack. ${ }^{42}$

In terms of deployment to the act, the Guidance indicates that, where a specific act requires prior geographic deployment, the deployment is considered an integral part of the act in question to the extent that the physical displacement is undertaken with a view to carry out a specific operation. $^{43}$

Concerning the end of the act, according to the Guidance, an individual is no longer directly participating in hostilities when he has physically separated from the operation, notably by laying down his weapons and resuming activities distinct from that operation. ${ }^{44}$ As with preparatory acts, the experts agreed that utmost care had to be taken, as well as situational pragmatism exercised, when deciding whether a civilian had effectively "returned" and regained protection from direct attack. To engage such civilians long after their withdrawal, when they no longer posed a threat, could be viewed as coming close to punishment. On the

41. GUIDANCE, supra note 20, at 65-67.

42. InT'L COMMITTEE OF THE RED CROSS, SuMMARY REPORT OF THE FOURTH EXPERT MEETING ON THE Notion of DiRect PARTICIPATION In Hostilities 60-61 (2006) [hereinafter 2006 REPORT], available at http://www.icrc.org/Web/eng/siteeng0.nsf/htmlall/direct-participation-article-020709/\$File/ 2006-03-report-dph-2006-icrc.pdf.

43. GUIDANCE, supra note 20 , at 67.

44. Id. at 67-68. 
other hand, expecting armed forces not to attack individuals who had directly participated in hostilities as soon as they started withdrawing from the location, could give rise to other operational and humanitarian concerns, especially in guerrilla warfare situations with increased risks to civilians. $^{45}$

To recap, a civilian loses protection when and for such time as he directly participates in hostilities. After the commission of the act, protection from direct attack is restored. What if the civilian's engagement is not a solitary incident? Does the civilian regain protection between each engagement, only to lose it when actual direct participation is occurring, or is the civilian subject to direct attacks even during the interval periods? The Guidance explains that unlike members of organized armed groups who lose protection for as long as they assume a continuous combat function, the loss of protection of civilians who directly participate in hostilities is only temporarily suspended, and not continuous. ${ }^{46}$ Circumstances in the battlefield are complex and ever changing. As such, even if a civilian has repeatedly participated in hostilities, future conduct is likely to be difficult to anticipate. Of course, if an individual repeatedly and in an organized manner, rather than sporadically and spontaneously, directly participates in hostilities, it could be argued that his behaviour is more akin to someone with a continuous combat function, such as a member of an organized armed group. ${ }^{47}$

For a number of experts, this "revolving door" concept was problematic. ${ }^{48}$ It was suggested that it was operationally untenable to argue that civilians could "'opt in' and 'opt out' of the conduct of hostilities," especially if they were to participate not just once, but twice or thrice. ${ }^{49}$ For these experts, such repeated engagement represented "a 'continuous mode' of direct participation in hostilities." ${ }^{, 50}$ An example given of such continuous engagement was the "civilian who fired at a military convoy from a hiding position and who then returned home just to conceal his weapon and wait for the next occasion to ambush a convoy."

\footnotetext{
45. 2006 Report, supra note 42, at 61-63.

46. GUIDANCE, supra note 20 , at 70 .

47. Id. at 71 .

48. 2008 Report, supra note 40 , at 36 .

49. Id.

50. Id.

51. Id. at 38 .
} 
With the concept of hostile intent included in the rules of engagement of a number of armed forces, such viewpoints arguably muster weight. ${ }^{52}$ Indeed, operationally, soldiers might be endangered were they to wait for a civilian, who has on a number of previous occasions directly participated in hostilities, to commit another hostile act before engaging. Yet, on the other hand, it may be that the civilian is no longer a threat, for instance because he was previously forced by insurgents to participate in hostilities, and therefore should be entitled to protection. Recognizing these difficult operational realities, the Guidance underscores the need to protect civilians from erroneous or arbitrary attacks.

Given that an individual directly participating in hostilities is subject to direct attack, possibly through the use of lethal force, recommendations eight and nine speak to the precautions that must be taken before and during the attacks and to the restraints that must be exercised during the use of force. ${ }^{53}$ As such, all feasible precautions must be taken in determining whether a person is a civilian and, if so, whether that civilian is directly participating in hostilities. "[F] easible precautions are understood to be those that are practicable or practically possible taking all the circumstances ruling at the time, including humanitarian and military precautions." ${ }^{54}$ In case of doubt, the person must be presumed to be protected against direct attack. Feasible precautions as to whether a civilian is directly participating in hostilities are to be taken not only before the launching of an attack, but also during the attack, so that it can be suspended if it appears that the civilian is in fact entitled to protection. ${ }^{55}$

Recommendation nine also notes that, "[i]n addition to the restraints imposed by international humanitarian law on specific means and methods of warfare, and without prejudice to further restrictions that may arise under other applicable branches of international law, the kind and degree of force which is permissible against persons [who are] not entitled to protection against direct attack must not exceed what is actually necessary to accomplish a legitimate military purpose in the prevailing circumstances." 56 The reports of the experts' meetings reflect the extensive discussions that surrounded the inclusion of this recommendation and its

52. Hostile intent is defined as "the threat of imminent use of force against the United States, US forces or other designated persons or property. It also includes the threat of force to preclude or impede the mission and/or duties of US forces, including the recovery of US personnel or vital USG property." See OPERATIONAL LAW HANDBOOK, supra note 16 , at 75.

53. GUIDANCE, supra note 20, at 74-82.

54. 2006 Report, supra note 42, at 69.

55. GUIDANCE, supra note 20, at 74 .

56. Id. at 77 . 
legal basis. ${ }^{57}$ In including the recommendation, the ICRC explained notably that "it would defy basic notions of humanity to kill an adversary or to refrain from giving him an opportunity to surrender where there is manifestly no necessity for the use of lethal force."

Finally, recommendation ten explains the loss of protection from direct attack is temporary, to the extent that it is linked to when the individual is directly participating in hostilities or to his or her continuous combat function in an organized armed group. ${ }^{59}$ When civilians cease to directly participate in hostilities, or when members of organized armed groups belonging to a non-state party to an armed conflict cease to assume their continuous combat function, they regain full civilian protection against direct attack, but they are not exempted from prosecution for violations of domestic and international law they may have committed.

As indicated above, the Guidance reflects the ICRC's position of how existing law should be interpreted and is not an attempt to change existing rules of customary and treaty IHL. The many views expressed by the experts during the various meetings highlighted the myriad difficulties of trying to address this delicate as well as emotive aspect of IHL: the mingling of belligerents amongst the civilian population increases the risk of erroneous targeting of civilians, but also makes the task of military personnel that much more difficult as they operate in hostile and complex environments.

\section{CONCLUSION}

A greater presence of non-state actors in contemporary armed conflicts has given risen to new humanitarian concerns regarding the protection of civilians and has created new challenges to ensuring the respect of IHL. In the fog of modern wars, finding the right balance between humanity and military necessity can be difficult, but it is essential to do so if the suffering and destruction caused by war are to be limited.

57. See 2008 Report, supra note 40, at 7-32.

58. GUIDANCE, supra note 20 , at 82.

59. Id. at $83-85$. 